\title{
Deep Scientific Drilling to Study Reservoir-Triggered Earthquakes in Koyna, Western India
}

\author{
by Harsh Gupta, Shailesh Nayak and the Koyna Workshop Committee
}

doi:10.2204/iodp.sd.12.07.2011

\section{Introduction}

During 21-25 March 2011, the International Workshop on Scientific Deep Drilling in the Koyna region in western India was held. It was organized by the National Geophysical Research Institute (NGRI), Hyderabad. The main objective of the workshop was to discuss a proposal for deep scientific drilling down to earthquake focal depths of $\sim 7 \mathrm{~km}$ at Koyna, a classical site of Reservoir Triggered Seismicity (RTS) in an intra-plate setting, and to design a comprehensive experiment through discussions with national and international experts. Participants of the workshop included seismologists, geologists, and drilling experts, many of them associated with active fault zone drilling projects worldwide, such as the San Andreas Fault Observatory at Depth (SAFOD) in California, the Chelungpu Fault Drilling Project in Taiwan, the Nojima Fault Drilling in Japan, the Gulf of Corinth in Greece, and the Latur Fault of India. There were twenty-six international participants from Canada, France, Germany, Italy, Japan, New Zealand, Poland, Taiwan, and the U.S.A., and fifty Indian participants represented major earth science organizations, institutes, and universities within the country. The workshop was supported by the Ministry of Earth

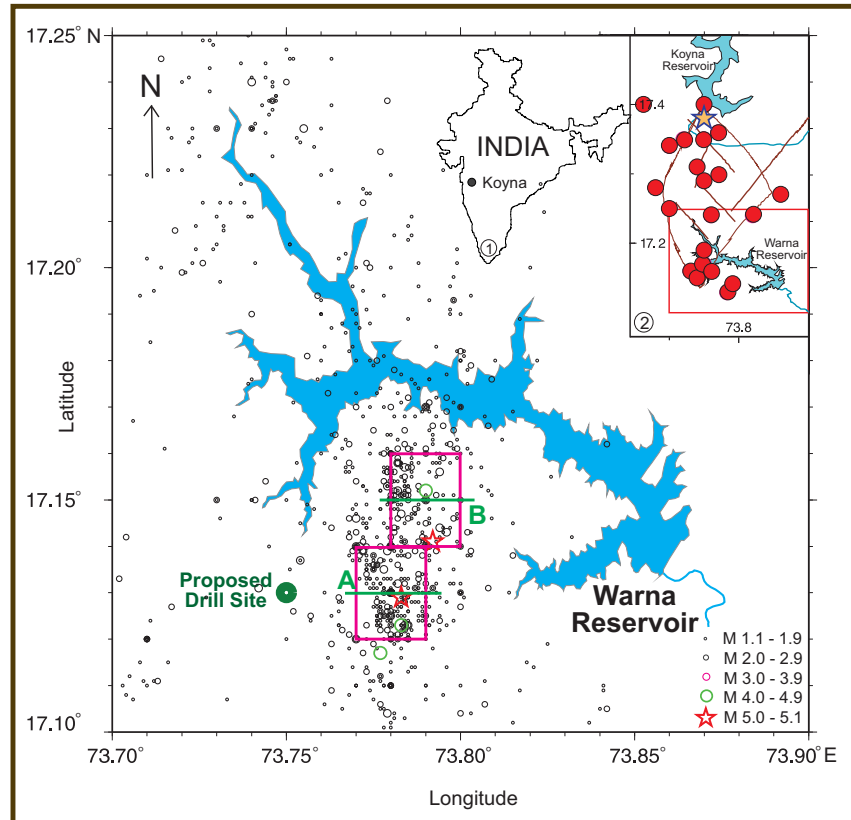

Figure 1. Seismicity in the Warna region south of Koyna, western India, during 2009-10 (red rectangle in inset 2). Inset 1: Map of India indicating the Koyna region; Inset 2: Earthquakes of magnitude 5 and above in the Koyna-Warna region since 1967.
Sciences (MoES), Government of India, and the International Continental Scientific Drilling Program (ICDP).

The Koyna region near the west coast of India is globally the premier site of RTS, where induced earthquakes have been occurring in a restricted area of $20 \times 30 \mathrm{~km}$ since the impoundment of Shivajisagar Lake in 1962. These include the largest triggered earthquake of $\mathrm{M} \sim 6.3$ on 10 December 1967 and twenty-one earthquakes of $\mathrm{M}>5$ since 1962 (Fig. 1). The RTS was further enhanced by impoundment of the nearby located Warna reservoir in 1993. The seismic zone is quite isolated with no other source of activity within $50 \mathrm{~km}$ of the Koyna Dam. The continued seismicity in an isolated zone that can be easily monitored provides a unique opportunity to directly measure the physical and mechanical properties of rocks, pore fluid pressure, hydrology, temperature, and other parameters of an intra-plate active fault zone in the "near-field" of earthquakes before, during, and after their occurrence. The focal depths, especially in the Warna region to the south, are mostly within $7 \mathrm{~km}$ (Fig. 1), and they can be accessed by drilling with available expertise. This active seismic zone, therefore, forms an ideal site to set up a borehole observatory which will permit direct and continuous monitoring of an intra-plate seismic zone at depth, leading to a better understanding of the mechanics of faulting and the physics of reservoir triggered earthquakes, and it will contribute appreciably to earthquake hazard assessment and forecasting.

\section{Structure of the Workshop}

The initial part of the workshop had four thematic sessions including (i) Global Review of Reservoir Triggered Seismicity, Models and Hypotheses, (ii) Geology and Geophysics of the Koyna Region, (iii) Global Status of Drilling into Fault Zones, and (iv) Designing the Koyna Scientific Drilling Experiment. The presentations provided an up-to-date status of expertise on fault drilling projects worldwide and brought out the core issues with respect to deep drilling investigations in the Koyna region. The next phase of the workshop included a field trip to the Koyna region and breakout group discussions for detailed planning of the required investigations. The participants were divided into four breakout groups based on their expertise: (i) Seismology/Borehole Location(s)/RTS, (ii) Drilling/ Coring/Geological Logging/Fault Zone Studies, (iii) Geophysical Logging/Petrophysical Properties/Long-term 
Monitoring, and (iv) Temperature/Hydrogeology/ Fluid and Gas Sampling. The breakout group discussions started at Hyderabad and continued through the field visit to Koyna and for another full day at Karad. The hallmark of the event was the gathering of experts from all major fault zone drilling programs worldwide, all working together to address the major challenges of undertaking the deep drilling investigations at Koyna.

\section{Suggested Site for Deep Borehole}

A borehole site for deep scientific drilling (green dot in Fig. 1, about $2 \mathrm{~km}$ west of block) was suggested on the basis of observed seismicity in the past two years (2009 and 2010), accessibility, and other logistic considerations. In Fig. 1, hypocenters are plotted of earthquakes of magnitude M1.1 and larger that occurred during 2009 and 2010 in block A. The seismic activity has been quite intense, as there were 81,26 , and 5 events of M1.1 to M1.9, M2.0 to M2.9, and M3.0 to M3.9, respectively. During 2009 and 2010 there was also one earthquake each of M4.3 and 5.0 in block A. A majority of these events are confined within a focal depth of $1-5 \mathrm{~km}$ in block A.

\section{Outcome of the Workshop}

All the participants at the workshop agreed that Koyna is an outstanding world-class geological site and a natural seismic laboratory to conduct a deep borehole experiment for earthquake studies. The MoES has declared its support to the program, and the ICDP has offered to make available its technical expertise in deep drilling and logging, training of manpower, and support towards drilling after receiving a successful drilling proposal. Experts from around the world have offered to bring in new tools and techniques for measurements and modeling.

On the basis of intensive discussions among the participants and important suggestions received from experts from India and abroad, a few key areas were identified for detailed preliminary studies. Foremost among these is the need to understand the hydrology of the region and connectivity between the reservoirs and host country rock. We also need to constrain the fine structure of the seismic zone in the area including detailed mapping of the causative faults, both of which would be critical in locating the deep borehole observatory in the region. The following three-tiered action plan was agreed upon.

1. Revisiting old data and acquiring new data

- Compile all available earthquake data for Koyna area and apply the most appropriate techniques to improve hypocenter locations.

- Deploy a larger number of seismic stations, especially in the region close to the active Warna seismic zone.
- Take up geophysical surveys like seismic reflection, magnetotelluric, deep electrical sounding, gravity and magnetics to constrain the fine structure of the seismic zone.

- Acquire very high-resolution Light Detection And Ranging (LIDAR) data.

\section{Studying hydraulic connectivity}

- Initially drill about four test boreholes around the seismic zone, each penetrating about $200 \mathrm{~m}$ into the preTrappean basement.

- Perform suites of measurements on geochemical and geophysical parameters in and across these boreholes.

- Model regional hydraulic connectivity.

\section{Plan the main borehole based on 1 and 2 .}

The workshop provided an excellent opportunity for the global community of concerned scientists to discuss the ideas and data collected and results obtained from the Koyna site of RTS for over the last four decades. The suggestions and plan of action as summarized above is now being implemented.

\section{Authors}

Harsh Gupta, National Geophysical Research Institute (CSIR-NGRI), Uppal Road, Hyderabad, 500 007, India; e-mail: harshg123@gmail.com.

Shailesh Nayak, Ministry of Earth Sciences (MoES), C.G.O. Complex, Lodhi Road, New Delhi 110 003, India.

and the Koyna Workshop Committee: Y.J. Bhaskar Rao, R.K. Chadha, B.K. Bansal, D. Srinagesh, N. Purnachandra Rao, Sukanta Roy, H.V.S. Satyanarayana, D. Shashidhar, and K. Mallika. 